$$
\begin{aligned}
R^{\prime} \mathrm{CONH} R+\mathrm{H}_{2} \mathrm{SO}_{4} \stackrel{\text { Fast }}{\rightleftharpoons} R^{\prime} \mathrm{CON}^{+} \mathrm{H}_{2} R+\mathrm{HSO}_{3}^{-} \\
R^{\prime} \mathrm{CO}-\mathrm{N}_{-}^{+} \mathrm{H}_{2} R \stackrel{\text { Slow }}{\rightarrow} R^{\prime} \mathrm{CO}^{+}+R \mathrm{NH}_{2}
\end{aligned}
$$

the slow step being followed by rapid conversion of the amine to its conjugate acid, and of the acyl ion to the corresponding carboxylic acidium ion ${ }^{5}$.

A fuller account of this work will be published later. J. A. Duffy J. A. LLFISTEN

Department of Chemistry,

University of Sheffield. Sept. 13.

'Ingold, C. K. "Structure and Mechanism in Organic Chemistry", 784 (Bell, 1953).

2 See, tor example, Taylor, J. W. J., J. Chem. Soc., 2741 (1930).

${ }^{3}$ Reid, E. E., Amer. Chem. J., 21, 284 (1899); 24, 397 (1900). Meloche,

I., and Laidler, K. J., J. Amer. Chem. Soc,, 73, 1712 (1951).

- de Roo and Bruylants, A., Bull. Soc. chim. Belges., B3, 140 (1954).

'Leisten, J. A., J. Chem. Soc., 298 (1955); 1572 (1956).

\section{Detection by Paper Electrophoresis of the Protein Denaturation in Heat- inactivated Serum for the Complement Fixation Reaction}

IN seeking the mechanism to explain an apparent procomplementary activity to canine complement of canine serum activated at $56^{\circ} \mathrm{C}$. for $30 \mathrm{~min}$., it was observed that the same serum was anticomplementary if inactivated at $62^{\circ} \mathrm{C}$. instead of $56^{\circ} \mathrm{C}$.

Wiggin ${ }^{1}$ suggested that the anticomplementary action of serum depends on the relationship between the protein ratio in the serum being tested and that in the serum being used as a source of complement. Since in the above case both the serum and complement originated from the same animal, experiments were designed to find out whether serum inactivation at $62^{\circ} \mathrm{C}$. affected the protein ratio.

Hæmoglobin-free sera which were obtained from healthy adult dogs were used throughout the present work. The sera were clarified by centrifugation at 3,500 r.p.m. and pooled. Fresh or heated (at $56^{\circ} \mathrm{C}$, $62^{\circ} \mathrm{C}$. or $65^{\circ} \mathrm{C}$.) samples of the serum-pool were applied in $0.01 \mathrm{ml}$. amounts to Whatman No. 1 filter paper strips for electrophoretic separation of

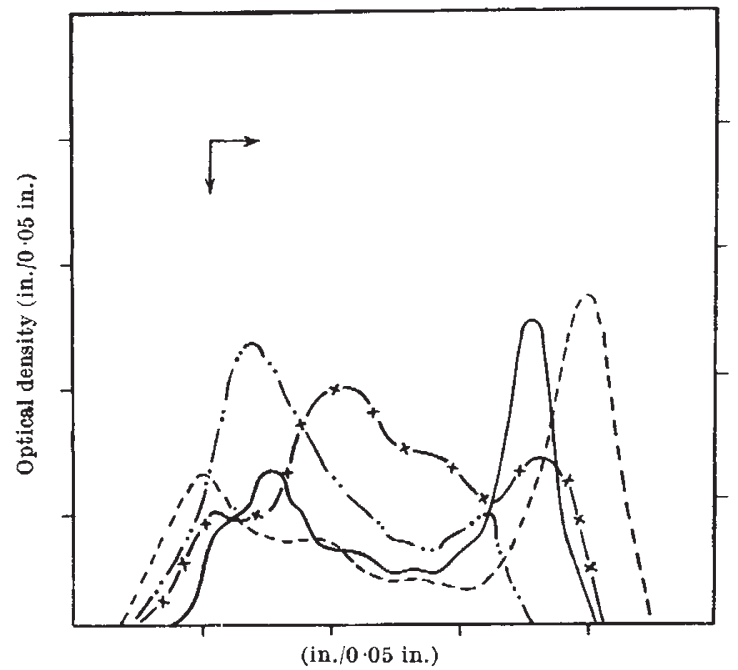

Fig. 1. Paper electrophoresis of canine serum either fresh (full line) or heated for $30 \mathrm{~min}$. at different temperatures (broken lines) : $\ldots, 56^{\circ} \mathrm{C}$. : $-\times-x, 62^{\circ} \mathrm{C}$. ; - $\cdots \cdots 5^{\circ} \mathrm{C}$. Arrows indicate site of application and direction of run

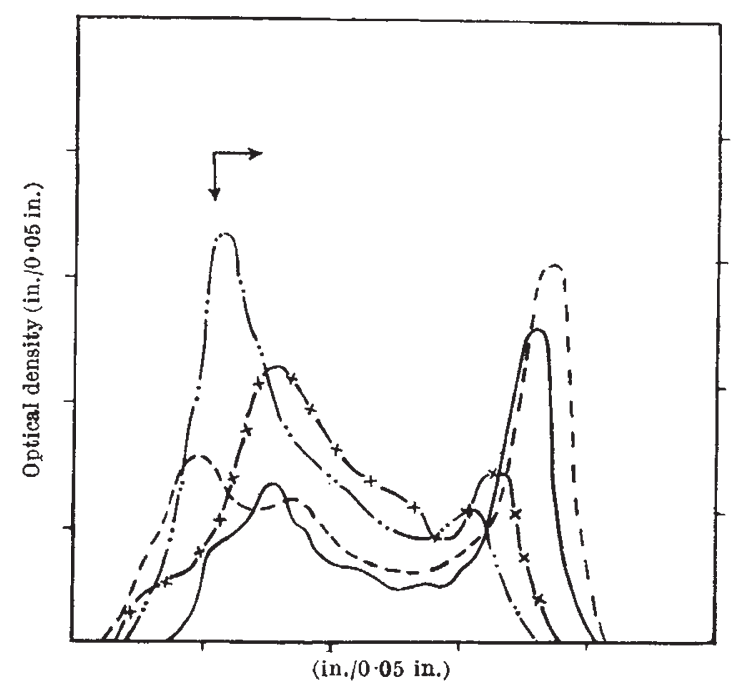

Fig. 2. Paper electrophoresis of canine serum either fresh (full line) or heated for $1 \mathrm{hr}$, at different temperatures (broken lines). ,$-- 56^{\circ} \mathrm{C}$. ; $-\times-\times, 62^{\circ} \mathrm{C} . ;-\ldots-\ldots, 65^{\circ} \mathrm{C}$. Arrows indicate site of application and direction of run

the proteins. The electrophoresis equipment in use was X118 'EEL' (Evans Electroselenium, Ltd.). The buffer solution was $30.0 \mathrm{gm}$. sodium barbitone, $19.5 \mathrm{gm}$. sodium acetate (hydrated) and $205.0 \mathrm{ml}$. $\mathrm{N} / 10$ hydrochloric acid (these were made up to 3 litres of distilled water). The electrophoresis proceeded in two baths (total 12 strips) for $29 \mathrm{hr}$. at a current of 0.75 m.amp. per strip. Paper strips were stained with $0 \cdot 25$ per cent bromphenol blue and 95 per cent ethanol saturated with mercuric chloride. Quantitative evaluation of proteins on the paper was by direct photometry of the strip.

Fig. 1 shows that heating of canine serum markedly affected electromigration of the protein particles. It is apparent that after heating serum at $56^{\circ} \mathrm{C}$. for $30 \mathrm{~min}$. the protein particles migrated faster if compared with unheated serum. Heating of serum at $62^{\circ} \mathrm{C}$. or $65^{\circ} \mathrm{C}$. for $30 \mathrm{~min}$. reduced considerably the electromigration. Here the protein was strongly adsorbed in the paper and formed patterns which were entirely different from those obtained with unheated serum. The protein denaturation, as shown in Fig. 2, was more marked in samples of serum which were heated at the above temperatures for I hr. instead of $30 \mathrm{~min}$.

These experiments suggest that the serum protein can be denatured by temperatures which are commonly used for inactivating serum for the complement-fixation reaction. Detection by paper electrophoresis of protein denaturation at these temperatures has not hitherto been described. Secondly, it seems that, as a function of the serum protein, the procomplementary or anticomplementary activity probably depends on the electric charge on the protein particle in the serum being tested.

A full account of these and related experiments will be published elsewhere.

The Animal Health Trust,

N. M. LaRIN

Virology Laboratory,

Canine Research Station,

Kennett, Nr. Newmarket. Sept. 20.

${ }^{1}$ Wiggin, N. J. B., Ph.D. thesis, Department of Pathology, Eniversity of Cambridge (1955). 